\title{
DESKRIPSI PROSES KOGNITIF SISWA SMP DALAM MENYELESAIKAN MASALAH MATEMATIKA BERDASARKAN MODES OF REPRESENTATIONTEORI BRUNER
}

\author{
Anisa Rizki Amalia, Tri Nova Hasti Yunianta \\ Universitas Kristen Satya Wacana Salatiga \\ Corresponding Author: 202015012@student.uksw.edu
}

\begin{abstract}
There are three steps of cognitive processes, that is: 1) acquire new information, 2) transform information; and 3) test the relevance and accuracy of knowledge or evaluation. This study aims to describe the students the cognitive process of junior high school to solve mathematical problems based on Bruner's three modes of representation. The research is qualitative descriptive. The subjects were three students of junior high school; each of them is with high, medium, and low abilities. The results showed that the cognitive processes of high and medium abilities were able to acquire information and transform it to solve the problems in the enactive, iconic, and symbolic representation. For the testing relevance and accuracy, high-ability subject only works in the enactive representation. Middle-ability does in the enactive and symbolic representation. The low-ability subject was able to do all three cognitive processes on questions the enactive representation, but other questions in the iconic and symbolic representation cannot be solved.
\end{abstract}

Keywords: Cognitive process; Mathematical problems; Modes of representation, Bruner's theory.

How to cite: Amalia, A. (2019). Deskripsi Proses Kognitif Siswa SMP dalam Menyelesaikan Masalah Matematika Berdasarkan Modes of representation Teori Bruner. Jurnal Review Pembelajaran Matematika, 4(1), 58-71.

\section{PENDAHULUAN}

Pembelajaran matematika berperan penting dalam mengembangkan ilmu pengetahuan dan teknologi (Kementerian Pendidikan dan Kebudayaan, 2017). Pembelajaran matematika erat kaitannya dengan pemecahan masalah berupa pertanyaan dan soal abstrak. Pemecahan masalah sendiri menurut Hudojo (Rif'atul \& Kurniasari, 2016) merupakan suatu proses yang dilakukan oleh siswa untuk menyelesaikan masalah yang sedang dihadapinya sampai masalah tersebut tidak lagi menjadi suatu masalah bagi siswa. Sumargiyani dan Hibatallah (2015) menyatakan bahwa pemecahan masalah tidak hanya sebagai bentuk kemampuan dalam mengaplikasikan informasi yang sudah diketahui melalui kegiatan belajar saja, melainkan lebih dari itu, merupakan suatu proses untuk memperoleh informasi yang terbukti dapat diterapkan sesuai dengan situasi yang sedang dihadapi. Pemecahan masalah matematika adalah aktivitas kognitif yang digunakan dalam proses untuk mengatasi suatu masalah yang sedang dihadapi seseorang dengan memerlukan beberapa strategi (Harahap \& Surya, 2017).

Penyelesaian masalah dapat membantu siswa untuk dapat mengembangkan suatu kemampuan dalam berpikir, memecahkan suatu masalah, serta mengembangkan keterampilan intelektualnya (Safrida, Susanto, \& Kurniati, 2015). Sejalan dengan itu, Adhar 
(2012) menyatakan bahwa kemampuan dalam pemecahan masalah sangat penting dalam pelajaran matematika. Tidak hanya untuk mereka yang akan belajar matematika, akan tetapi bermanfaat untuk seseorang yang akan menerapkannya dalam bidang pelajaran lainnya maupun dalam kehidupan sehari-hari. Hal ini diperkuat dengan pendapat Yarmayani (2016) yang menyatakan bahwa kemampuan pemecahan masalah matematika yaitu kemampuan dimana siswa mencoba mencari jalan keluar untuk mencapai tujuan dalam menyelesaikan suatu masalah. Jadi, pemecahan masalah adalah keterampilan dasar yang harus dimiliki oleh setiap orang.

Proses kognitif siswa merupakan gabungan antara pengetahuan yang sudah diperoleh siswa melalui indra tubuh manusia dengan pengetahuan yang sudah ada di dalam memori jangka panjang. Kemampuan pengelolaan suatu pengetahuan dibatasi dengan kapasitas memori dan faktor waktu. Sebagai akibat dari terjadinya suatu proses kognitif, maka terjadi suatu tindakan yang terpilih, yaitu proses kognitif dan proses fisik berupa gerakan anggota tubuh dan anggota suara. Tindakan lainnya juga dapat berupa tindakan pasif dengan aktivitas yang dapat dilakukan (Kuswana, 2013). Menurut El-idhami (2009) proses kognitif siswa berlangsung secara bertahap hingga menuju kesempurnaan. Proses kognitif juga dapat membantu anak dalam berpikir lebih kompleks dan bernalar dalam memecahkan suatu masalah. Pemecahan masalah matematika salah satunya dapat menggunakan tahapan belajar Bruner.

Proses kognitif menurut Bruner ada tiga tahap, yaitu: 1) tahap memperoleh informasi baru; 2) tahap mentransformasi informasi; dan 3) tahap menguji relevansi dan ketepatan pengetahuan atau evaluasi. Informasi baru merupakan proses penghalusan informasi sebelumnya yang dimiliki seseorang. Dalam transformasi informasi seseorang mengolah pengetahuan yang diperolehnya, dengan cara mengeksplorasi atau dengan mengubah menjadi bentuk lain. Pada tahap menguji relevansi dan ketepatan pengetahuan, yang dilakukan menilai apakah cara memperlakukan pengetahuan itu cocok dengan tugas yang ada (Wilis, 2011).

Hampir semua orang dapat melalui penggunaan tiga sistem keterampilan untuk mengembangkan keterampilan yang sudah dimilikinya secara sempurna. Ketiga sistem keterampilan tersebut disebut tiga cara penyajian (modes of representation), yang meliputi: 1) enactive, seseorang belajar tentang dunia melalui aksi-aksi terhadap benda nyata; 2) iconic, pembelajaran terjadi melalui penggunaan model-model dan gambaran-gambaran; dan 3) symbolic, menggambarkan kapasitas berpikir dalam istilah-istilah yang abstrak seperti simbol 
ataupun rumus.

Tidak semua siswa SMP dalam membuat penyelesaian masalah langsung menggunakan tahapan symbolic. Pada kenyataannya masih ada siswa yang menyelesaikan masalah dengan menggunakan tahapan iconic terlebih dahulu. Berikut adalah gambar yang menyatakan hal tersebut.

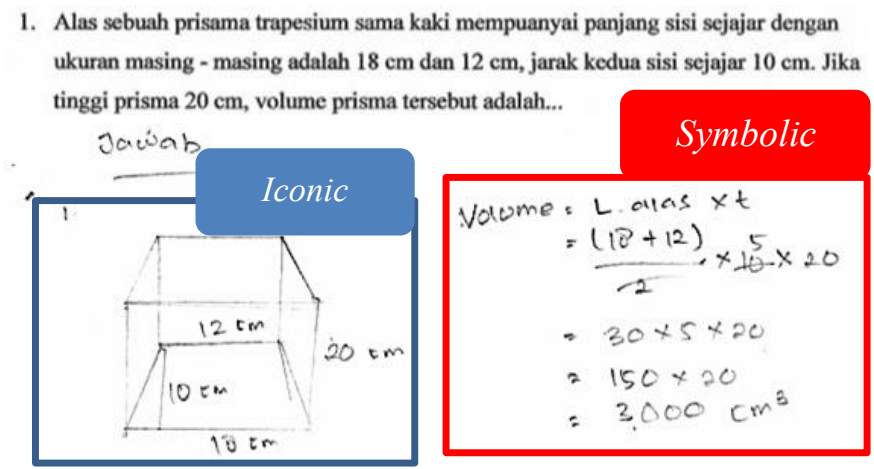

Gambar 1. Contoh Penyelesaian Masalah Bangun Ruang

Melihat pada bagian yang diberikan Gambar 1 dengan kotak biru memperlihatkan penyelesaian masalah siswa menggunakan cara iconic terlebih dahulu dengan menggambarkan bangun ruang dan dilanjutkan dengan menggunakan tahap symbolic. Hal ini sejalan dengan Rosanti, Rizal, dan Ismaimuza (2014) yang menyatakan bahwa siswa SMP seharusnya sudah tidak terkait lagi dengan objek pada tahap sebelumnya dan siswa pada tahap ini harus mampu menggunakan notasi atau simbol matematika bukan menggunakan benda nyata. Oleh karena itu, perlu adanya tindak lanjut yang dapat melatih siswa dalam menyelesaikan masalah matematika. Apabila siswa dalam menyelesaikan masalah materi bangun ruang sisi datar siswa mengalami kesulitan dan memerlukan bantuan media nyata maupun gambar, maka guru dapat memberikan stimulus berupa rumus bangun ruang agar siswa terbiasa menyelesaikan masalah dengan simbol matematika. Guru dapat membiasakan siswa dalam menyelesaikan masalah dengan menggunakan simbol matematika secara langsung. Misalnya ketika menyelesaikan soal cerita guru menuliskan rumus yang digunakan untuk menyelesaikan masalah. Oleh karena itu, tujuan dalam penelitian ini adalah untuk mendeskripsikan proses kognitif siswa SMP dalam menyelesaikan masalah matematika berdasarkan modes of representation teori Bruner.

\section{METODE PENELITIAN}

Penelitian ini merupakan penelitian kualitatif dengan pendekatan deskriptif. Subjek 
dalam penelitian ini yaitu siswa kelas IX-A SMP Negeri 1 Ambarawa dan sudah mempelajari materi bangun ruang sisi datar. Penelitian ini diawali dengan menentukan tingkat kemampuan siswa pada penilaian tengah semester kemudian mengambil tiga subjek yaitu, subjek dengan kemampuan matematika tinggi (TS), subjek dengan kemampuan matematika sedang (RK), dan subjek dengan kemampuan matematika rendah (AP). Kemampuan proses berpikir subjek baik secara lisan maupun tertulis juga menjadi pertimbangan dalam menentukan subjek. Teknik pengumpulan data dengan tes, dimana siswa diminta menyelesaikan masalah secara individu. Soal tes yang terdiri dari tiga soal uraian dengan pendekatan soal materi bangun ruang sisi datar sesuai dengan tahap modes of representation teori Bruner yaitu, tahap enactive, iconic, dan symbolic digunakan peneliti untuk mengetahui proses kognitif siswa dalam menyelesaikan masalah matematika. Berikut instrumen soal tes yang diberikan kepada subjek.

Tabel 1. Soal Tes dengan pendekatan modes of representation teori Bruner

\begin{tabular}{|c|c|}
\hline Enactive & $\begin{array}{l}\text { Perhatikan enam bangun ruang limas segi empat yang ditempelkan pada jaring-jaring kubus! } \\
\text { Jika enam bangun ruang limas disusun menjadi suatu bangun ruang kubus dan perbandingan } \\
\text { antara tinggi kubus dengan tinggi limas adalah } 1: 2 \text {, maka carilah rumus volume dari bangun } \\
\text { ruang limas segi empat. }\end{array}$ \\
\hline Iconic & $\begin{array}{l}\text { (a) } \\
\text { (a) gambar banguı เ uang kubus sempurna aan (D) gambar bangun ruang kubus terpancung } \\
\text { dengan salah satu titik sudutnya dipotong dengan potongannya membentuk limas segitiga. } \\
\text { Jika panjang rusuk kubus 6a cm dan panjang rusuk tegak limas segitiga } 2 \frac{1}{3} a \mathrm{~cm} \text {, maka volume } \\
\text { bangun ruang kubus terpancung adalah... }\end{array}$ \\
\hline Symbolic & $\begin{array}{l}\text { Sebuah kaleng berbentuk balok dengan ukuran bagian dalam kaleng adalah } 10 \mathrm{dm} \times 8 \mathrm{dm} \times \\
6 \mathrm{dm} \text { berisi air penuh. Bila air itu dituangkan pada kaleng lain berbentuk prisma yang luas } \\
\text { alasnya } 96 \mathrm{dm}^{2} \text { dan tingginya } 9 \mathrm{dm} \text {. Berapa dm tinggi air pada kaleng berbentuk prisma? }\end{array}$ \\
\hline
\end{tabular}

Selanjutnya hasil yang sudah diperoleh diperkuat dengan wawancara tidak terstruktur untuk mendapatkan informasi yang lebih lanjut dan mendalam mengenai proses kognitif subjek. Data yang sudah terkumpul, selanjutnya dilakukan analisis untuk memperoleh informasi yang diinginkan dengan mereduksi data. Dalam mereduksi data, data dirangkum dan mengambil hal-hal yang dirasa penting. Setelah data dirangkum, selanjutnya dilakukan penyajian data. Tahapan selanjutnya dilakukan verifikasi dengan menyimpulkan temuan baru yang sudah diperolehnya.

Adapun kriteria dalam melakukan penarikan kesimpulan adalah jika dalam menyelesaikan soal pada tahapan enactive, iconic, dan symbolic subjek dapat melalui tiga proses 
kognitif yaitu, tahap memperoleh informasi, mentransformasi informasi, dan tahap menguji relevansi atau ketepatan, maka subjek dapat dikatakan mampu mengembangakan keterampilan intelektualnya dan proses kognitif subjek berkembang dengan baik. Akan tetapi, jika subjek tidak mampu melalui salah satu dari tiga proses kognitif tersebut, maka subjek dianggap belum mampu mengembangkan keterampilan intelektualnya dan proses kognitif subjek tidak berkembang dengan baik.

Langkah terakhir yang dilakukan adalah dengan melihat keabsahan data. Menurut Sugiyono (2012), dalam pemeriksaan keabsahan data dilakukan dengan kredibilitas. Kredibilitas dalam penelitian ini dilakukan menggunakan teknik triangulasi metode. Langkah yang dilakukan dengan cara membandingkan dan mengecek kembali informasi dari data yang diperoleh melalui metode tes, metode dokumentasi, dan metode wawancara.

\section{HASIL DAN PEMBAHASAN}

Hasil analisis soal tes masalah matematika dengan pendekatan tahap modes of representation teori Bruner berdasarkan hasil pekerjaan dari 3 siswa disajikan berdasarkan tipe soal berikut:

\section{Analisis Proses Kognitif Siswa dalam Menyelesaikan Soal Terhadap Enactive Berdasarkan Modes of representation Teori Bruner}

Tahap 1, yaitu memperoleh informasi baru. Pada tahap ini, TS, RK, dan AP mampu menggali informasi dari soal pendekatan tahap enactive meskipun ketiga subjek tidak menuliskan apa saja yang diketahui pada soal. Akan tetapi ketiga subjek menyebutkan secara lisan ketika wawancara. Subjek TS menyebutkan 3 hal yang diketahui dan yang ditanyakan pada soal dengan mengadopsi beberapa kalimat yang dituliskan pada soal, seperti cuplikan hasil wawancara berikut.

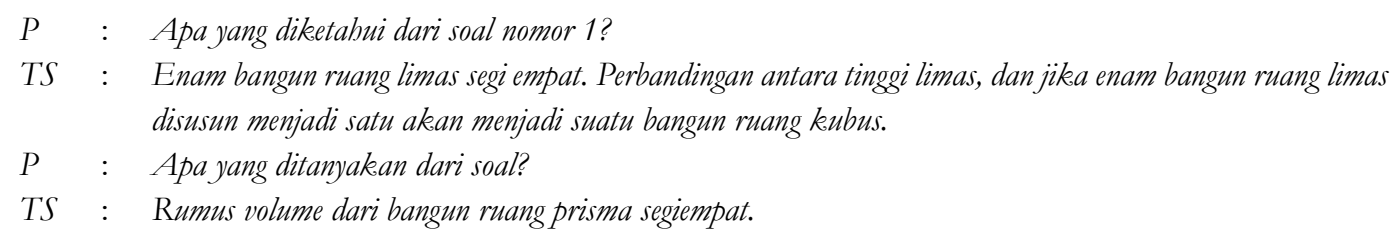

Subjek RK hanya menyebutkan perbandingan yang diketahui dan yang ditanyakan pada soal, hal tersebut dapat dilihat dari cuplikan hasil wawancara berikut.

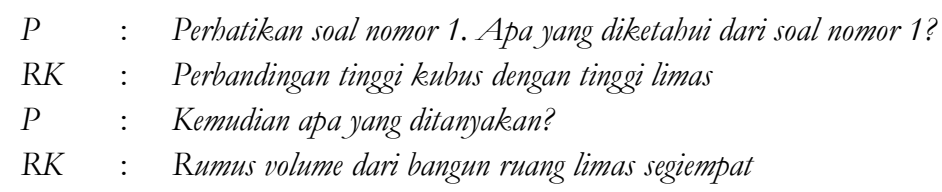

Subjek AP awalnya ragu dalam menyebutkan yang diketahui pada soal kemudian subjek AP 
mengadopsi kalimat yang diketahui dan ditanyakan pada soal, hal tersebut dapat dilihat dari cuplikan hasil wawancara berikut.

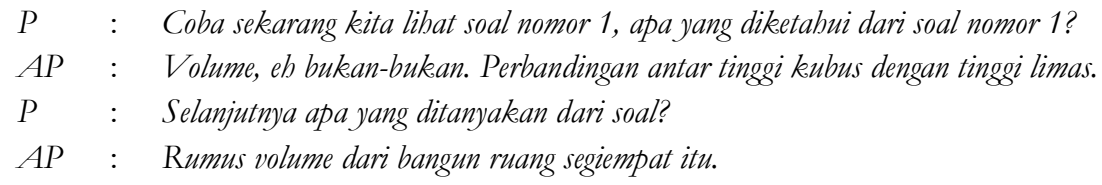

Tahap 2, yaitu mentransformasi informasi. Pada tahap ini, semua subjek TS, RK, dan AP mampu mentransformasi informasi pada tahap enactive. Subjek TS mampu menuliskan langkah penyelesaian soal secara runtut yaitu dengan menuliskan perbandingan banyak bangun ruang yang diketahui dari soal kemudian mampu membuat permisalan dalam menyelesaikan masalah. Hal ini dapat dilihat pada Gambar 2 berikut.
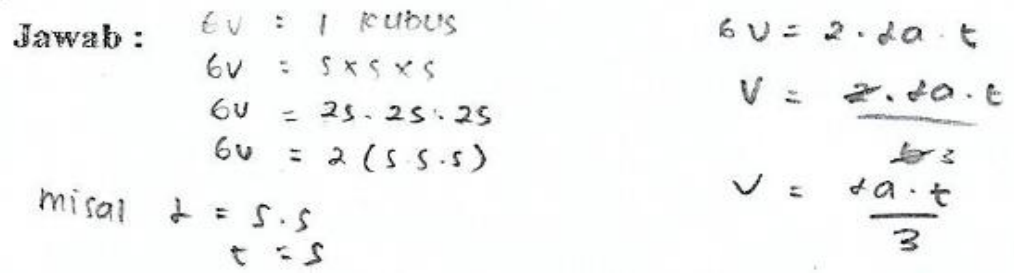

Gambar 2. Hasil Pekerjaan Subjek TS Tahap Enactive

Subjek RK mampu menuliskan langkah penyelesaian secara runtut meskipun memiliki penyelesaia yang berbeda dengan subjek TS. Hal ini dapat dilihat pada Gambar 3 berikut.

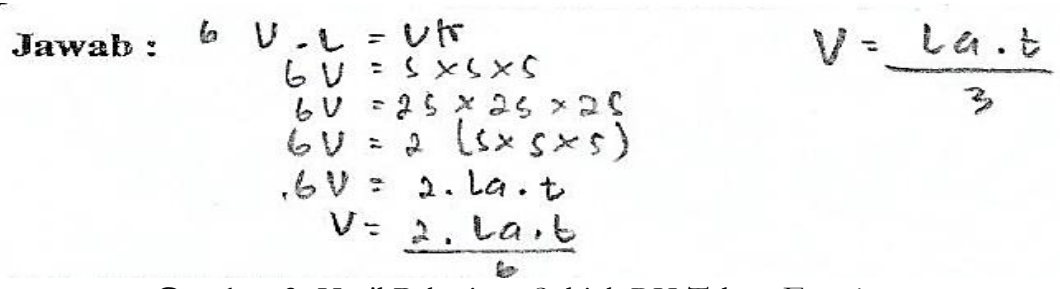

Gambar 3. Hasil Pekerjaan Subjek RK Tahap Enactive

Tahap 3, yaitu menguji relevansi dan ketepatan. Subjek TS dan Subjek RK sudah melakukan uji ketepatan pada tahap enactive yang diberikan, meskipun langkah yang dituliskan oleh subjek berbeda seperti yang dapat dilihat pada Gambar 2 dan Gambar 3, namun hasil yang diperoleh subjek sudah tepat. Subjek AP juga sudah melakukan uji ketepatan akan tetapi subjek AP hanya menuliskan sepenggal langkah yang subjek ketahui seperti pada Gambar 4 berikut.

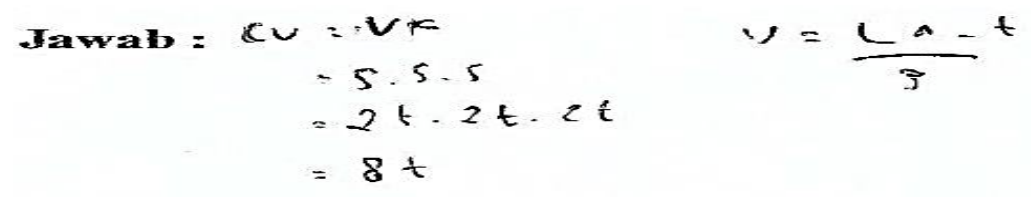

Gambar 4. Hasil Pekerjaan Subjek AP Tahap Enactive

Persamaan proses kognitif subjek TS, RK dan AP dalam menyelesaikan masalah tahap enactive 
dapat dilihat pada Tabel 2 berikut.

Tabel 2. Proses Kognitif Subjek Pada Tahap Enactive

\begin{tabular}{cccc}
\hline \multirow{2}{*}{ Proses Kognitif } & \multicolumn{3}{c}{ Enactive } \\
\cline { 2 - 4 } & TS & RK & AP \\
\hline Memperoleh Informasi Baru & $\checkmark$ & $\checkmark$ & $\checkmark$ \\
Mentransformasi Informasi & $\checkmark$ & $\checkmark$ & $\checkmark$ \\
Menguji Relevansi dan Ketepatan & $\checkmark$ & $\checkmark$ & $\checkmark$ \\
\hline
\end{tabular}

Proses kognitif ketiga subjek pada tahap enactive sudah berkembang dengan baik, subjek mampu melakukan ketiga proses kognitif secara bertahap dimana pada tahap memperoleh informasi ketiga subjek mampu menggali informasi dengan menyebutkan apa yang diketahui pada soal, kemudian mentransformasikan informasi tersebut dengan menuliskan penyelesaian dari soal meskipun ketiga subjek mempunyai cara masing-masing dalam menyelesaian soal. Dalam menguji relevansi dan ketepatan ketiga subjek sudah dapat melakukannya meskipun masing-masing subjek memiliki cara yang berbeda dalam menguji ketepatan.

\section{Analisis Proses Kognitif Siswa dalam Menyelesaikan Soal Terhadap Iconic Berdasarkan Modes of representation Teori Bruner}

Tahap 1, yaitu memperoleh informasi baru. Pada tahap ini, subjek TS dan RK dapat menggali informasi dari apa yang diketahui dan ditanyakan pada tahap iconic. Sedangkan subjek AP hanya mampu menyelesaikan tahap enactive, subjek AP masih tidak dapat membayangkan bangun ruang yang terpotong dan subjek AP merasa kesulitan dalam menyelesaikan soal tahap iconic, hal ini dapat kita lihat pada cuplikan hasil wawancara berikut.

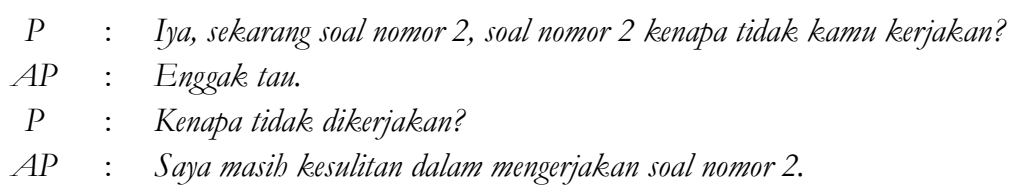

Subjek TS mampu menyebutkan apa yang diketahui dan ditanyakan pada soal. Hal ini dapat dilihat dari cuplikan wawancara berikut.

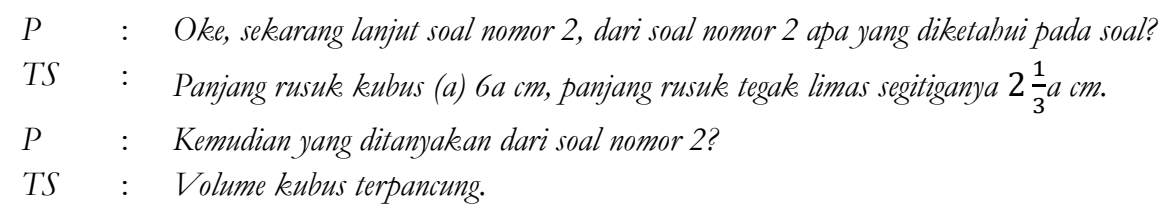

Subjek RK pada tahap memperoleh informasi juga mampu menyebutkan apa yang diketahui, akan tetapi subjek tidak menyebutkan besaran panjang rusuknya selain itu subjek juga dapat menyebutkan apa yang diketahui pada soal, hal ini dibuktikan dari hasil cuplikan wawancara berikut.

P : Oke, sekarang lanjut soal nomor 2, dari soal nomor 2 apa yang diketabui pada soal? 


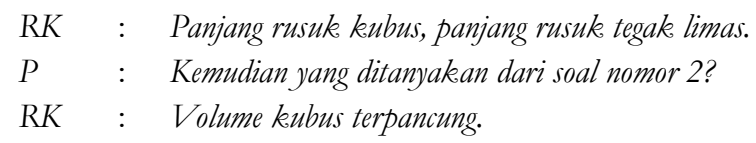

Tahap 2, yaitu mentransformasi informasi. Subjek TS mampu mentransformasikan informasi yang sudah subjek peroleh subjek mampu menuliskan informasi yang subjek ketahui yaitu, dengan menuliskan langkah-langkah yang subjek gunakan dalam menyelesaikan masalah. Hasil pekerjaan subjek dapat dilihat pada Gambar 5.

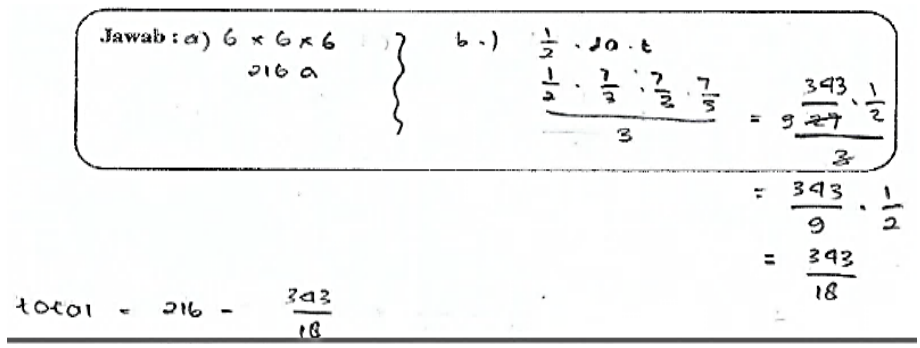

Gambar 5. Hasil Pekerjaan Subjek TS Tahap Iconic

Subjek RK sudah melaksanakan tahap mentransformasi informasi, subjek mampu mengolah informasi yang subjek dapatkan dengan mentransformasikan informasi pada langkahlangkah dalam menjawab tahap iconic. Hasil pekerjaan subjek dapat dilihat pada Gambar 6.

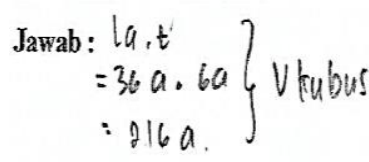

$: 216 a$.

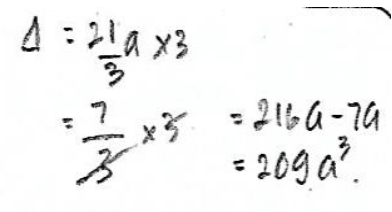

$\therefore 70$

Gambar 6. Hasil Pekerjaan Subjek RK Tahap Iconic

Tahap 3, yaitu menguji relevansi dan ketepatan. Pada tahap ini, kedua subjek TS dan RK tidak melakukan koreksi dalam menyelesaikan soal tahap iconic dimana seperti pada Gambar 5 dan Gambar 6 dapat dilihat bahwa hasil akhir yang subjek dapatkan belum tepat. Subjek TS sudah paham dengan apa yang harus subjek lakukan dalam menyelesaikan soal tersebut meskipun subjek tidak melakukan koreksi dalam menjawab soal dan subjek merasa tidak yakin dengan hasil akhirnya. Hal ini dibuktikan dari hasil cuplikan wawancara berikut.

$P \quad: \quad$ Kemudian coba jelaskan cara kamu menyelesaikannya.

TS : Langkah pertama yang dicari volum bangun (a) dulu, diperoleh 216 a kemudian langkah yang kedua mencari volume bangun ruang (b) tapi kalau jawabannya belum selesai mengerjakannya.

$P \quad: \quad B a i k$, tetapi apakah kamu tau bagaimana cara mencari volume dari bangun ruang yang (b)?

TS : Iya tau, ini dari volume yang (a) itu dikurangi sama yang terpancung.

Subjek RK hanya menjelaskan bagaiman cara subjek memperoleh hasil yang ditanyakan pada soal saja dan subjek tidak melakukan koreksi kembali terhadap soal yang diberikan, hal ini dapat dibuktikan dalam hasil cuplikan wawancara berikut. 
$P \quad: \quad Y a$, kemudian sekarang coba jelaskan cara kamu menyelesaikannya!

RK : Yang pertama mencari volume kubus (a). Kemudian mencari besar volume limas segitiga, setelah itu dikurangkean voleme kubus (a) dikurangi dengan volume limas sehingga diperoleh volume kubus terpancung.

Perbedaan proses kognitif subjek TS, RK dan AP dalam menyelesaikan masalah tahap iconic dapat dilihat pada Tabel 3 berikut.

Tabel 3. Proses Kognitif Subjek Pada Tahap Iconic

\begin{tabular}{cccc}
\hline \multirow{2}{*}{ Proses Kognitif } & \multicolumn{3}{c}{ Iconic } \\
\cline { 2 - 4 } & TS & RK & AP \\
\hline Memperoleh Informasi Baru & $\checkmark$ & $\checkmark$ & - \\
Mentransformasi Informasi & $\checkmark$ & $\checkmark$ & - \\
Menguji Relevansi dan Ketepatan & - & - & - \\
\hline
\end{tabular}

Proses kognitif ketiga subjek TS, RK, dan AP pada tahap iconic masih belum mampu mengembangkan proses kognitif secara baik. Subjek TS dan RK mampu menggali informasi dari soal meskipun tidak tertulis dan mampu menyusun pemecahan masalah meskipun memiliki langkah yang berbeda, namun subjek TS dan RK tidak melakukan uji ketepatan dimana hasil yang diperoleh subjek belum tepat. Subjek AP pada tahap iconic tidak mampu mengembangkan proses kognitifnya, subjek masih merasa kesulitan dalam menyelesaikan soal pada tahap iconic.

\section{Analisis Proses Kognitif Siswa dalam Menyelesaikan Soal Terhadap Symbolic Berdasarkan Modes of representation Teori Bruner}

Tahap 1, yaitu memperoleh informasi baru. Pada tahap ini, hanya 2 subjek yang mampu menggali informsai dalam menyelesaikan masalah tahap symbolic yaitu subjek TS dan RK, subjek TS dapat menyebutkan hal-hal yang diketahui dan ditanyakan pada tahap symbolic meskipun subjek TS tidak menuliskannya dengan mengadopsi kalimat pada soal, hal ini dibuktikan dari hasil cuplikan wawancara berikut.

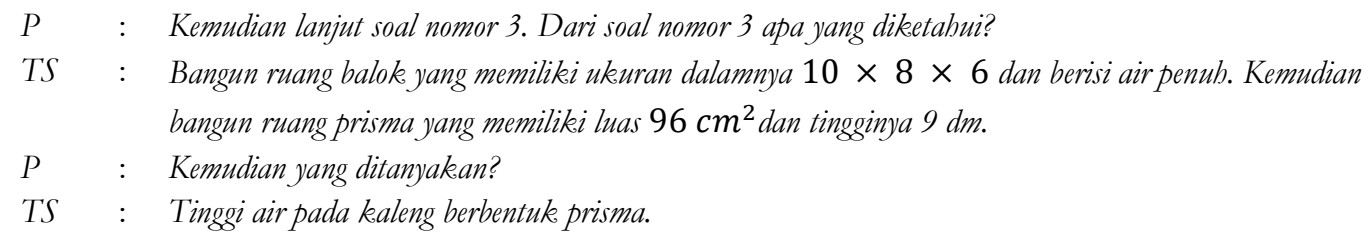

Subjek RK juga dapat menyebutkan informasi dari tahap symbolic, subjek dapat menyebutkan apa yang diketahui pada soal dan apa yang ditanyakan. Subjek meyebutkan yang diketahui dalam soal secara jelas meskipun subjek tidak menyebutkan besaran bilangan yang diketahui hal ini dibuktikan dalam hasil wawancara berikut.

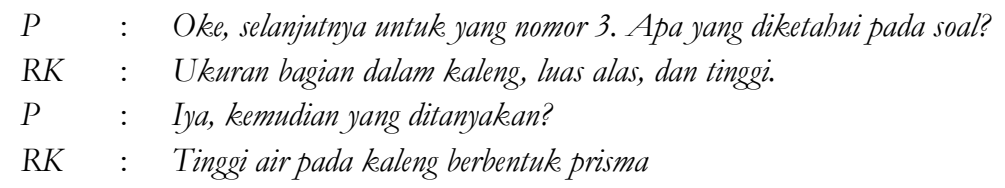


Di lain pihak, subjek AP tidak mampu mengembangkan proses kognitifnya. Subjek merasa kesulitan dalam menyelesaikan tahap symbolic hal ini dibuktikan dari hasil wawancara berikut.

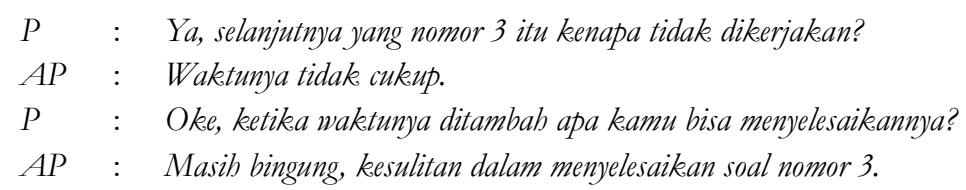

Tahap 2, yaitu mentransformasi informasi. Pada tahap ini hanya subjek TS dan RK yang mampu mentransformasikan informasi yang sudah diperoleh subjek sebelumnya.

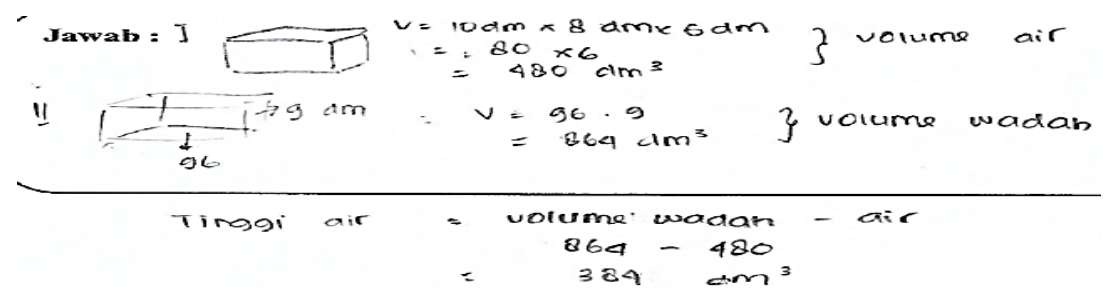

Gambar 7. Hasil Pekerjaan Subjek TS Tahap Symbolic

Subjek TS dalam mentransformasikan informasinya yaitu dengan menggambar terlebih dahulu bangun ruang yang diketahui seperti pada Gambar 7, subjek TS harus kembali ke tahap iconic terlebih dahulu baru melanjutkan ke tahap symbolic dengan menerapkan rumusrumus yang sudah subjek ketahui. Hal ini juga dibuktikan dalam kutipan wawancara berikut.

$P \quad$ : Sekarang coba jelaskan cara kamu menyelesaikan!

TS : Langkah pertama saya menggambar terlebih dabulu kemudian mencari volume yang balok yang diperoleh hasil akbirnya $480 \mathrm{dm}^{3}$ langkah selanjutnya yang kedua itu mencari volum prisma diperoleh hasilnya 864 $\mathrm{dm}^{3}$ kemudian hasilnya kita kurangkan $864-480=384$.

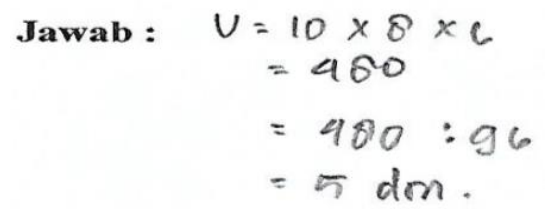

Gambar 8. Hasil Pekerjaan Subjek RK Tahap Symbolic

Subjek RK dalam menyelesaikan tahap symbolic dapat memanfaatkan informasi yang sudah subjek peroleh dari soal, subjek mampu mengaplikasikan informasi pada soal dan menerapkannya pada rumus yang subjek ketahui, hal ini dapat dilihat pada hasil pekerjaan subjek seperti pada Gambar 8. Selain itu subjek juga mampu menjelaskan hasil yang dituliskan subjek hal ini dapat dibuktikan pada kutipan wawancara berikut.

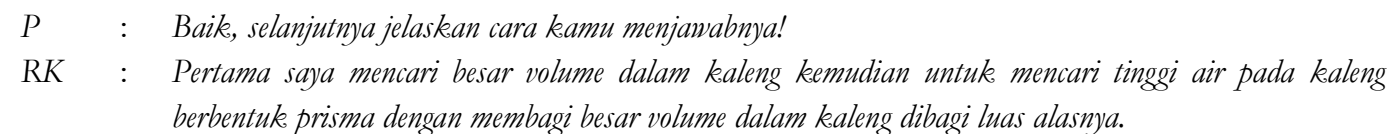

Tahap 3, yaitu menguji relevansi dan ketepatan. Pada tahap ini, hanya subjek RK saja yang mampu menguji ketepatan, subjek merasa yakin dengan hasil yang subjek peroleh 
seperti pada Gambar 8, karena subjek melakukan koreksi dalam menyelesaikan tahap symbolic, hal ini dapat dibuktikan dari hasil wawancara berikut.

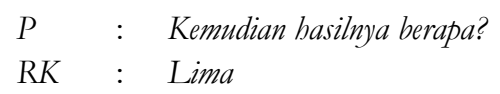

Perbedaan proses kognitif subjek TS, RK, dan AP dalam menyelesaikan masalah tahap symbolic dapat dilihat pada Tabel 4 berikut.

Tabel 4. Proses Kognitif Subjek Pada Tahap Symbolic

\begin{tabular}{cccc}
\hline \multirow{2}{*}{ Proses Kognitif } & \multicolumn{3}{c}{ Symbolic } \\
\cline { 2 - 4 } & TS & RK & AP \\
\hline Memperoleh Informasi Baru & $\checkmark$ & $\checkmark$ & - \\
Mentransformasi Informasi & $\checkmark$ & $\checkmark$ & - \\
Menguji Relevansi dan Ketepatan & - & $\checkmark$ & - \\
\hline
\end{tabular}

Proses kogitif ketiga subjek TS, RK, dan AP dalam menyelesaikan masalah tahap symbolic dapat dilihat pada Tabel 3. Dimana hanya subjek RK yang mempunyai kemampuan proses kognitif baik dapat dilihat subjek RK mampu melewati ketiga proses kogitif dengan cara menggali informasi meskipun tidak tertulis, mampu merancang penyelesaian dan mampu menguji relevansi dengan tepat. Pada tahap ini subjek TS hanya mampu menggali informasi dengan menyebutkan apa yang diketahui dan menuliskan langkah penyelesaian meskipun subjek tidak melakukan uji ketepatan. Subjek AP pada tahap symbolic juga merasa kesulitan dalam menyelesaikan masalah yang diberikan.

Terkait dengan hasil analisis yang diperoleh di atas, terdapat perbedaan tahapan proses kognitif yang dilakukan oleh subjek dengan kategori tinggi, sedang, dan rendah dalam menyelesaikan tipe soal tahap enactive, tahap iconic, dan tahap symbolic yang dirangkum pada Tabel 5 berikut.

Tabel 5. Perbedaan Proses Kognitif Siswa Dalam Menyelesaikan Soal Berdasarkan Modes of representation Teori Bruner

\begin{tabular}{cccccccccc}
\hline \multirow{2}{*}{ Proses Kognitif } & \multicolumn{3}{c}{ Enactive } & \multicolumn{3}{c}{ Iconic } & \multicolumn{3}{c}{ Symbolic } \\
\cline { 2 - 10 } & TS & RK & AP & TS & RK & AP & TS & RK & AP \\
\hline $\begin{array}{c}\text { Memperoleh Informasi } \\
\text { Baru }\end{array}$ & $\checkmark$ & $\checkmark$ & $\checkmark$ & $\checkmark$ & $\checkmark$ & - & $\checkmark$ & $\checkmark$ & - \\
\hline $\begin{array}{c}\text { Mentransformasi Informasi } \\
\text { Menguji Relevansi dan } \\
\text { Ketepatan }\end{array}$ & $\checkmark$ & $\checkmark$ & $\checkmark$ & $\checkmark$ & $\checkmark$ & - & $\checkmark$ & $\checkmark$ & - \\
\hline
\end{tabular}

Berdasarkan hasil analisis dan Tabel 5, dapat dilihat bahwa subjek TS dalam menyelesaikan soal pada tahap menerima enactive mampu melakukan semua tahap proses kognitif. Subjek TS dalam menyelesaikan soal pada tahap iconic dan symbolic hanya mampu melakukan dua proses kognitif yaitu memperoleh informasi dan mentransformasi informasi. Subjek RK mampu melakukan semua tahapan pada proses kognitif dalam menyelesaikan soal tahap enactive dan symbolic. Akan tetapi, subjek RK dalam menyelesaikan soal tahap iconic 
hanya mampu melalui 2 tahap proses kognitif yaitu tahap memperoleh informasi dan mentransformasi informasi, subjek tidak melakukan uji relevansi atau ketepatan. Subjek AP dalam menyelesaikan soal pada tahap enactive mampu melakukan semua tahap pada proses kognitif. Akan tetapi pada soal tahap iconic dan symbolic subjek tidak mampu melakukan ketiga tahap proses kognitif. Hal itu bertentangan dengan penelitian yang dilakukan oleh Susanti (2015) yang menyatakan bahwa subjek dengan kategori tinggi memiliki proses kognitif yang baik dimana subjek mampu melakukan ketiga tahap dalam proses kognitif untuk menyelesaikan masalah matematika. Untuk subjek dengan kategori sedang dalam penelitian Susanti (2015), subjek mampu melakukan tiga tahap proses kognitif meskipun ada beberapa masalah dalam menyelesaikan soal sehingga mengakibatkan hasil akhirnya belum tepat. Untuk subjek dengan kategori rendah dalam penelitian Susanti (2015) subjek mampu melakukan semua tahapan proses kognitif, akan tetapi subjek cenderung memiliki profil proses berpikir yang kurang karena pada ketiga tahap proses kognitif siswa hanya dapat menyebutkan beberapa jawaban dari soal yang diberikan oleh peneliti. Hal ini terjadi karena adanya perbedaan dalam pendekatan soal tes. Dalam studi ini, peneliti dalam mengambil data menggunakan soal dengan pendekatan modes of representation teori Bruner materi bangun ruang, sedangkan Susanti (2015) menggunakan soal pemecahan masalah materi bangun ruang.

\section{SIMPULAN DAN SARAN}

Berdasarkan hasil penelitian, dapat disimpulkan bahwa subjek dengan kategori tinggi dan sedang mampu memperoleh informasi dan mentransformasikannya dalam menyelesaikan soal pada tahap enactive, iconic, dan symbolic. Akan tetapi, subjek dengan kategori tinggi dalam menguji relevansi dan ketepatan hanya melakukan pada soal tahap enactive saja sedangkan subjek dengan kategori sedang melakukan uji relevansi dan ketepatan pada soal pendekatan enactive dan symbolic. Subjek dengan kategori rendah mampu melakukan ketiga proses kognitif pada saat mengerjakan soal tahap enactive saja. Namun, mengalami kesulitan menyelesaikan soal tahap iconic dan symbolic.

Saran yang dapat diberikan dalam pembelajaran, guru dapat membiasakan siswa untuk mengerjakan soal matematika khususnya pada materi bangun ruang dengan pendekatan soal symbolic seharusnya diselesaikan secara langsung dengan memanfaatkan rumus yang sudah diketahui siswa, sehingga siswa dapat mengembangkan pengetahuan intelektualnya dengan baik. 


\section{DAFTAR RUJUKAN}

Adhar, L. E. (2012). Pembelajaran Matematika Dengan Metode Penemuan Terbimbing Untuk Meningkatkan Kemampuan Representasi dan Pemecahan Masalah Matematis Siswa SMP. Jurnal Penelitian Pendidikan, 13(2), 1-9. Retrieved from http://jurnal.upi.edu/file/Leo_Adhar.pdf.

El-idhami, D. (2009). Psikologi Perkembangan Peserta Didik. Bandung: PT. Remaja Rosdakarya.

Harahap, E. R. \& Surya, E. (2017). Kemampuan Pemecahan Masalah Matematis Siswa Kelas VII Dalam Menyelesaikan Persamaan Linear Satu Variabel. Edumatica: Jurnal Pendidikan Matematika, 7(1), 44-54. Retrieved from https://onlinejournal.unja.ac.id/index.php/edumatica/article/view/3874.

Himmah, N. R. \& Kurniasari, I. (2016). Profil Pemecahan Masalah Matematika Model PISA Berdasarkan Kemampuan Matematika Siswa SMA. MATHEdunesa: Jurnal Ilmiah Pendidikan Matematika, 3(5), 1-10. Retrieved from https://jurnalmahasiswa.unesa.ac.id/index.php/mathedunesa/article/view/18573/1 6947

Kementerian Pendidikan dan Kebudayaan. (2017). Implementasi Pengembangan Kecakapan Abad 21 Dalam Perencanaan Pelaksanaan Pembelajaran (RPP). Jakarta: Dit. PSMA Ditjen. Pendidikan Dasar dan Menengah. Diakses dari http://fip.upgris.ac.id/wpcontent/uploads/2017/06/1.-MODEL-IMPLEMENTASI -kec-abad-21.pdf

Kuswana, W. S. (2013). Taksonomi Berpikir. Bandung: PT Remaja Rosdakarya.

Rosanti, A. S, Rizal, M., \& Ismaimuza, D. (2014). Pengetahuan Siswa SMP Kelas VIII Dalam Memecahkan Masalah Matematika Non Geometri Berdasarkan Level 2 Perkembangan Berpikir Van Hiele. Jurnal Elektronik Pendidikan Matematika 2(1). Retrieved from http://jurnal.untad.ac.id/jurnal/index.php/JEPMT/article/view/3233

Safrida, L. N., Susanto, S., \& Kurniati, D. (2015). Analisis Proses Berpikir Siswa dalam Pemecahan Masalah Terbuka Berbasis Polya Sub Pokok Bahasan Tabung Kelas IX SMP Negeri 7 Jember. Kadikma, 6(1), 25-38. Retrieved from https://jurnal.unej.ac.id/index.php/kadikma/article/view/1825.

Sugiyono. (2012). Metode Penelitian Kombinasi (Mixed Methods). Bandung: Alfabeta.

Sumargiyani \& Hibatallah, M. I. (2018). Analisis Kemampuan Pemecahan Masalah Siswa Pada Materi Barisan dan Deret Siswa Kelas XI IPA MA Ali Maksum. In Prosiding Seminar Nasional Etnomatnesia. hal. 891-900. Retrieved from http://www.jurnal.ustjogja.ac.id/index.php/etnomatnesia/article/view/2433/1394

Susanti, V. (2015). Profil Kemampuan Berpikir Siswa dalam Memecahkan Masalah Matematika Berdasarkan Teori Bruner. Jurnal Penelitian Pendidikan, 7(2), 1181-1187. Retrieved from http://ejournal.stkippacitan.ac.id/index.php/jpp/article/view/34.

Wilis, R. D. (2011). Teori-teori Belajar dan Pembelajaran. Jakarta: PT Gelora Aksara Pratama. 
Deskripsi Proses Kognitif ...

Yarmayani, A. (2016). Analisis Kemampuan Pemecahan Masalah Matematis Siswa Kelas XI MIPA SMA Negeri 1 Kota Jambi. Jurnal Ilmiah DIKDAYA, 6(2), 12-19. Retrieved from http://dikdaya.unbari.ac.id/index.php/dikdaya/article/view/9. 